\title{
A Study on the Performance, Suitability and Economics of Pratapdhan Under Backyard Poultry Farming in Banswara District of Rajasthan
}

\author{
Bheroo Singh Bhati", Lekhu Kumar and Gopal Lal Kothari \\ Krishi Vigyan Kendra, Banswara, MPUAT, Udaipur, Rajasthan, INDIA \\ *Corresponding author: BS Bhati ; E-mail: bhati.bsbikaner@gmail.com
}

Received: 25 June, 2021

Revised: 20 July, 2021

Accepted: 24 July, 2021

\begin{abstract}
ABSTARCT
A study was conducted on Pratapdhan birds under backyard poultry rearing in Banswara district of Rajasthan. During the study four block of Banswara were selected randomly. 15 farmers from each block were randomly selected, 15 farmers awavy them having Pratapdhan poultry birds (beneficiaries under ARYA project) and rest 15 farmers having native poultry birds (non-beneficiaries) were selected out of 60 respondents. 20 Pratapdhan chicks per farmers provided by Krishi Vigyan Kendra, Banswara under ARYA project after training for the respondent of economic point of view. The impact of training on poultry farming was significantly high and average knowledge score of the trainees increased from 3.68 to 8.50 . The performance of dual purpose breed Pratapdhan was better under backyard poultry farming. The overall mean body weight, the mean eggs production were significantly $(\mathrm{P} \leq 0.05)$ higher in Pratapdhan poultry birds than native birds. The overall mortality rate of Pratapdhan poultry birds were significant lower $(\mathrm{P} \leq 0.05)$ than native birds. The benefit cost ratio of rearing in Pratapdhan poultry birds was recorded 1:5.15 per family. The income of small, marginal and landless poultry farmers were increased due to rearing of Pratapdhan poultry birds under backyard through low input and high output venture within a very short span of time. Pratapdhan poultry bird is one of the promising dual purpose strains of poultry, which can be popularized in rural areas of Banswara district of Rajasthan.
\end{abstract}

\section{HIGHLIGHTS}

( We studied Performance, Suitability and Economics of Pratapdhan under Backyard Poultry Farming.

(0 The Pratapdhan bird a dual purpose strain performs better than native bird.

(0 The income farmers were increased due to rearing of Pratapdhan birds under backyard poultry farming.

Keywords: Backyard Poultry, Economics, Growth Performance, Pratapdhan, Production

Backyard poultry farming plays an important role in the economic upliftment of poor farmers. Stress free and harmful residue free poultry obtained from backyard poultry farming get a great scope in the availability of quality meat. Poultry sector contributes about 36 per cent of total meat production in India (Department of Animal Husbandry, Dairying and Fisheries, 2018-19). Eggs contribute 3.77 per cent as value output from total livestock rearing. India shares 3.17 per cent of total poultry in the world, (Anonymous, 2018-19). The population of poultry under courtyard system is 317 million ( $20^{\text {th }}$ census). As per $20^{\text {th }}$ livestock census, there were 80.24 lacs poultry in Rajasthan, from which 30.33 lacs poultry were at backyard and remaining 49.91 lacs were at farm poultry. Generally, in rural areas farmers have been maintaining backyard poultry for income generation, home consumption, gifts and sacrifice for guests. Backyard poultry is a great need to increase the availability of protein food source in rural areas to alleviate protein malnutrition. This can be achieved by adopting poultry farming in small scale in the back yard

How to cite this article: Bhati, B.S., Kumar, L. and Kothari, G.L. (2021). A Study on the Performance, Suitability and Economics of Pratapdhan Under Backyard Poultry Farming in Banswara District of Rajasthan. $J$. Anim. Res., 11(04): 745-749.

Source of Support: None; Conflict of Interest: None 
of rural households or rearing them under intensive farm conditions in small numbers by utilizing locally available, less expensive feed and housing inputs. Backyard poultry is identified as a significant livelihood activity for many poor and landless families and particularly for women who looks for additional income. In traditional backyard poultry farming, farmer rears 5 to 10 indigenous birds which produce only 60 to 70 eggs per year and low meat production. The contribution of backyard poultry is only 11 per cent of total eggs production of the country The present per-capita availability of eggs is 54, while chicken meat consumption is $2.2 \mathrm{~kg}$ whereas, the ICMR recommendation is the consumption of 180 eggs and 10.8 $\mathrm{kg}$ poultry meat per person per annum (Shekhar and Ranjan, 2020). To increase the income of such family a need was to introduce Pratapdhan breed of backyard poultry for livelihood security of poor family. In the context of Indian poultry production, during the past four decades, poultry industry has transformed itself from the age-old backyard farming into a dynamic agri based industry.

Pratapdhan poultry were dual purpose and have found great acceptance and good adaptability to local conditions. It was developed as part of AICRP on Poultry Breeding by MPUAT, Udaipur. Attractive multi colour feather pattern, as rural people like coloured birds from aesthetic point of view and better looking. Because of colour plumage birds have camouflagic characters to protect themselves from predators. Longer shank length which help in self protection from predators in backyard areas. Good adaptability in backyard/ free-range, it has good immune competence as there is lack of availability of good quality food and drinking water, the birds have to roam into dirty surrounding in search of food. Further it has capacity to survive on low plane of nutrition (low and negligible input) and harsh climatic conditions. Produce brown shell egg and broody characteristic.

Hence, the rural poultry farming has good potential in the state especially in the rural areas to improve the socioeconomic condition and overcoming protein deficiency. So, that the present study has been undertaken pratapdhan poultry birds under backyard poultry rearing in Banswara district of Rajasthan.

\section{MATERIALS AND METHODS}

The present study was carried out by the Krishi Vigyan
Kendra, Banswara district of Rajasthan. Before start Poultry farming training programmes was organized under ARYA project on different aspect of scientific poultry farming for knowledge up gradation and skill development especially in rural youth. For this purpose Abaapura, Bagidora, Garhi and Kushalgarh block were selected for backyard poultry distribution under ARYA project during the year 201920. 15 farmers from each block were selected randomly making it a total of 60 respondents and 15 farmers of them having Pratapdhan poultry (beneficiaries under ARYA project) and rest 15 having Native poultry birds (non-beneficiaries) were selected out of 60 respondents for this study. Data were collected with the help of a semi structured interview schedule and through observation. Data so collected, tabulated and analyzed as per standard statistical procedures of Snedecor and Cochran (1994).

\section{RESULTS AND DISCUSSION}

\section{Knowledge level}

The study showed that most of the farmers are unaware and very less number of farmers were using scientific management techniques in poultry farm. The impact of training was significantly high and average knowledge score of the trainees increased from 3.68 to 8.50 (out of 10) as showed in Table 1. Importance of farmers training for successful poultry farming was also highlighted by earlier workers (Ram et al., 2017; Chatterjee and Rajkumar, 2015; Shekhar et al., 2019).

\section{Growth Performances}

Comparative data on body weight of different age groups ( 0 day to 40 weeks) are presented in Table 2 . The average body weights at 0 day, 4 week, 20 week and 40 weeks were recorded as $36.45 \pm 0.085,295.25 \pm 0.103$, $2075.25 \pm 1.123$ and $2455.15 \pm 1.045$ gram, respectively in Pratapdhan birds and in case of native birds $25.80 \pm 0.102$, $172.26 \pm 1.056,1222.75 \pm 1.852$ and $1495.50 \pm 1.631$ gram, respectively. It clearly indicated that the body weights of Pratapdhan birds were significantly $(\mathrm{P} \leq 0.05)$ higher than the corresponding body weights of native birds. The present findings are in accordance with the report of earlier workers (Khadda et al., 2017; Singh et al., 2018). The difference in body weights may be due to varied agro- 
climatic conditions, availability of feeding materials and management practices adopted by the farmers. More or less comparable body weight of native birds at 40 weeks of age is reported by Singh (1997).

Table 1: Knowledge level or score of poultry farmer (based on questionnaire)

\begin{tabular}{llll}
\hline \multirow{2}{*}{$\begin{array}{l}\text { S1. } \\
\text { No. }\end{array}$} & Farm Management Practices & \multicolumn{2}{c}{$\begin{array}{c}\text { Average Score } \\
\text { (Out of 10) }\end{array}$} \\
\cline { 3 - 4 } & & $\begin{array}{l}\text { Before } \\
\text { Training }\end{array}$ & $\begin{array}{l}\text { After } \\
\text { Training }\end{array}$ \\
\hline $1 \quad \begin{array}{l}\text { Backyard poultry breed, Brooding } \\
\text { and Housing }\end{array}$ & 4.65 & 8.51 \\
2 & $\begin{array}{l}\text { Disease Management and Schedule } \\
\text { Vaccination and deworming }\end{array}$ & 3.10 & 8.58 \\
$3 \quad \begin{array}{l}\text { Poultry Nutrition and Feed } \\
\text { formulation }\end{array}$ & 4.72 & 8.95 \\
$4 \quad \begin{array}{l}\text { Bio-securityand sanitation } \\
5\end{array} \quad$ Marketing and waste management & 2.95 & 8.10 \\
\hline Overall Average Score & 3.68 & 8.35 \\
\hline
\end{tabular}

Table 2: Growth Performances of Pratapdhan birds in comparison to native birds

\begin{tabular}{lll}
\hline \multirow{2}{*}{ Age of bird } & \multicolumn{2}{c}{ Body Weight (Gram) } \\
\cline { 2 - 3 } & Pratapdhan Bird & Native Bird \\
\hline Day old & $36.45 \pm 0.085$ & $25.80 \pm 0.102$ \\
1 Week & $95.23 \pm 0.182$ & $49.65 \pm 1.035$ \\
2 Week & $145.12 \pm 0.245$ & $70.85 \pm 0.945$ \\
4 Week & $295.25 \pm 0.103$ & $172.26 \pm 1.056$ \\
6 Week & $510.12 \pm 0.256$ & $225.42 \pm 2.045$ \\
8 Week & $695.14 \pm 0.202$ & $380.25 \pm 1.521$ \\
10 Week & $785.30 \pm 0.098$ & $508.25 \pm 0.564$ \\
1 2 Week & $1012.40 \pm 1.012$ & $650.45 \pm 0.845$ \\
14 Week & $1285.75 \pm 0.354$ & $770.49 \pm 2.457$ \\
16 Week & $1525.10 \pm 0.179$ & $921.25 \pm 1.094$ \\
18 Week & $1832.25 \pm 0.285$ & $1075.12 \pm 0.912$ \\
20 Week & $2075.25 \pm 1.123$ & $1222.75 \pm 1.852$ \\
40 Week & $2455.15 \pm 1.045$ & $1495.50 \pm 1.631$ \\
\hline
\end{tabular}

\section{Production performances}

The average age at sexual maturity in Pratapdhan birds and native birds were recorded to be $172.05 \pm 1.103$ and $195.52 \pm 1.965$ days, respectively (Table 3 ). Low age of sexual maturity 173 and 169 days recorded by Khadda et al. (2017) and Singh et al. (2018). The average egg production of Pratapdhan birds and native birds were recorded to be $162.15 \pm 0.462$ and 58.00 \pm 0.640 , respectively (Table 3). The average egg production of Pratapdhan birds was also significantly $(\mathrm{P} \leq 0.05)$ higher than native birds, which might be due to different genetic makeup of two groups. In contrast to present findings low egg production of 54.94 and 167.89 was recorded in 40 and 72 weeks respectively reported by Khadda et al. (2017). The average egg weights of Pratapdhan birds and native birds were $49.35 \pm 1.853$ and $42.50 \pm 0.965$ gram, respectively. The mortality rate during 0 to 4,5 to 20,21 to 40 and Above 40 weeks of age in Pratapdhan birds and in native birds under backyard poultry farming system of rearing is presented in the Table 3.

Table 3: Production Performances of Pratapdhan birds in comparison to native bird

\begin{tabular}{lll}
\hline Quantitative traits & $\begin{array}{l}\text { Pratapdhan } \\
\text { Bird }\end{array}$ & $\begin{array}{l}\text { Native } \\
\text { Bird }\end{array}$ \\
\hline Age at Sexual Maturity (Days) & $172.05 \pm 1.103$ & $195.52 \pm 1.965$ \\
Egg Production & $162.15 \pm 0.462$ & $58.00 \pm 0.640$ \\
Average Egg Weight (g) & $49.35 \pm 1.853$ & $42.50 \pm 0.965$ \\
Mortality 0 to 4 week (\%) & $10.00 \pm 0.751$ & $17.15 \pm 1.090$ \\
Mortality 5 to 20 week (\%) & $7.5 \pm 2.065$ & $14.24 \pm 1.325$ \\
Mortality 21 to -40 week (\%) & $2.45 \pm 0.150$ & $5.56 \pm 2.590$ \\
Above 40 weeks & $1.05 \pm 0.089$ & $3.05 \pm 0.923$ \\
\hline
\end{tabular}

There was significant $(\mathrm{P} \leq 0.05)$ low mortality rate in Pratapdhan birds as compared to native birds. The results of study indicate that survivability percentage of Pratapdhan birds in prevailing agro-climatic conditions of Banswara was well within the standard range 90-95 percent (Khan, 2008), which may be due to presence of good brooding, timely vaccination, good immune competence, disease resistance, ability to protect from predator and proper management practices followed by farmers.

\section{Economics of rearing poultry birds}

The total production cost i.e. cost of chick, feed, treatment, labour or housing cost of Pratapdhan birds and native birds was calculated ₹ 3155 and ₹ 1680, respectively (Table 4). The higher production cost in Pratapdhan birds might be due to higher feed and chick cost. The total gross income earned from sale of eggs and birds of Pratapdhan and 
Table 4: Economics of rearing Pratapdhan poultry birds comparison to native birds per family (20 birds) under backyard condition of Banswara district of Rajasthan

\begin{tabular}{|c|c|c|}
\hline Items & Pratapdhan Bird & Native Bird \\
\hline \multicolumn{3}{|l|}{ Cost of Day old chick } \\
\hline Rate of Pratapdhan Chick@ @ 75/chick & $75 \times 20=1500$ & $30 \times 20=600$ \\
\hline \multicolumn{3}{|l|}{ Rate of Deshi Chicks@ @ 30/chick } \\
\hline \multicolumn{3}{|l|}{ Cost of Feed } \\
\hline $\begin{array}{l}1.25 \mathrm{~kg} \text { of feed per bird for Pratapdhan Rate of feed } @ ₹ \\
25 / \mathrm{kg}\end{array}$ & $31.25 \times 25=625$ & $10 \times 15=150$ \\
\hline \multicolumn{3}{|l|}{$\begin{array}{l}500 \text { gm of Maize per bird for Native bird Rate of broken } \\
\text { rice @ ₹ } 15 / \mathrm{kg}\end{array}$} \\
\hline Treatment Cost & 200 & 100 \\
\hline Cost of Labour & 430 & 430 \\
\hline Housing Cost & 400 & 400 \\
\hline Total Cost & 3155 & 1680 \\
\hline $\begin{array}{l}\text { Income from sale of egg (10 Pratapdhan layer and } 10 \\
\text { local layer) Price of egg @ ₹ 10/Egg }\end{array}$ & $162 \times 10 \times 10=16,200$ & $58 \times 10 \times 10=5,800$ \\
\hline $\begin{array}{l}\text { Income from sale of cocks (Sale of } 4 \text { pratapdhan cock and } \\
4 \text { local cock) Price of cock @ ₹ 500/cock }\end{array}$ & $500 \times 4=2000$ & $500 \times 4=2000$ \\
\hline \multicolumn{3}{|l|}{$\begin{array}{l}\text { Income from sale of female birds (Sale of } 4 \text { female of } \\
\text { Pratapdhan and } 4 \text { female of local) }\end{array}$} \\
\hline Price of Pratapdhan female @ ₹ 300/Hen & $300 \times 4=1200$ & $250 \times 4=1000$ \\
\hline \multicolumn{3}{|l|}{ Price of Local Female @ ₹ 250/Hen } \\
\hline Total Gross income & 19,400 & 8,800 \\
\hline Net income & 16,245 & 7,120 \\
\hline $\mathrm{B}: \mathrm{C}$ ratio & 5.15 & 4.24 \\
\hline
\end{tabular}

native birds were ₹ 19,400 and ₹ 8800 , respectively (Table 4). The benefit cost ratio in Pratapdhan birds and native birds were recorded as 5.15 and 4.24, respectively (Table 4). The high benefit cost ratio 4.68 in CARI-Nirbheek birds was recorded by Khadda et al. (2017). Pratapdhan backyard poultry significantly role in increase income reported by Yadav et al. (2018). The higher benefit cost ratio in Pratapdhan birds was due to more egg production and body weight in the given period of time as compared to native birds. The comparative analysis revealed that the performance of Pratapdhan is very promising, can be promoted in large scale in the backyard poultry farming system.

\section{CONCLUSION}

It is concluded that training was one of the most important tools for knowledge up gradation and skill development among the poultry farmers. The Pratapdhan bird a dual purpose strain performs better than native bird. The phonotypical similarity particularly multi-coloured plumage, better adaptability and protected well from predator of Pratapdhan bird, it is well adopted by the farmers of the Banswara district of Rajasthan. The income of small, marginal and landless farmers was increased due to rearing of Pratapdhan birds under backyard poultry farming of Banswara through low input and high output venture within a very short span of time.

\section{ACKNOWLEDGEMENTS}

It is a great pleasure for me to express sincere and deepest sense of gratitude and indebtedness to authors and Staff of Krishi Vigyan Kendra, Banswara for his valuable inspiring 
guidance and encouragement during the research work and preparation of the manuscript.

\section{REFERENCES}

Anonymous, 2018-19. Department of Animal Husbandry, Dairying and Fisheries, Ministry of agriculture and farmers welfare, Govt. of India.

Chatterjee, R.N. and Rajkumar, U. 2015. An overview of poultry production in India. Ind. J. Anim. Healt., 54(2): 89-108.

Khadda, B.S., Lata, K., Kumar, R., Jadav, J.K., Singh, B. and Palod, J. 2017. Production performance and economics of CARI Nirbheek chicken for backyard farming under semiarid ecosystem in central Gujarat, India. Ind. J. Anim. Res., 51(2): 382-386

Khan, A.G. 2008. Indigenous breeds, crossbreeds and synthetic hybrids with modified genetic and economic profile for rural family and small scale poultry farming in India. World's Poult. Sci. J., 64: 405-415.
Ram, D., Singh, M.K. and Laishram, J.M. 2017. Training needs assessment of poultry farmers in Imphal West and Imphal East of Manipur. Inter. J. Curr. Micro. Appl. Sci., 6(9): 22182227.

Shekhar, S., Ranjan, R., Singh, C.V. and Singh, R.K. 2019. Evaluating Impact of Training on Backyard Poultry Farming Among Landless and Small Farmers of Koderma District. $J$. Comm. Mobiliz. Sust. Develop., 14(3): 543-546.

Shekhar, S. and Ranjan, R. 2020. Study the performance, suitability and economics of Cari-Nirbheek under backyard poultry farming in Koderma district of Jharkhand, India. $J$. Ento. Zool. Studi., 8(3): 930-934

Singh, D.K., Singh, M.K., Singh, P.K., Kumar, A. and Ahmad, F. 2018. Comparative Performance of CARI Nirbheek, Hitcari and CARI Shyama birds under backyard system of rearing in western Uttar Pradesh, India. J. Rur. Agri. Res., 18(2): 39-41.

Yadav, C.M., Bugalia, H.L., Ramawatar, Dadheech, S. and Dhakar, B. 2018. Economic of pratapdhan poultry under backyard system rearing in bhilwara district of Rajasthan, India. Inter. J. Curr. Micro. Appli. Sci., 7(8): 4242-4246 
